\begin{tabular}{|c|c|}
\hline Title & Polymorphisms in the muscarinic receptor 1 gene confer susceptibility to asthma in Japanese subjects. \\
\hline Author(s) & $\begin{array}{l}\text { Maeda, Y ukiko; Hizawa, Nobuyuki; Jinushi, Eisei; Honda, A yumi; T akahashi, Daisuke; Fukui, Y oshinobu; Konno, } \\
\text { Satoshi; Shimizu, T adamichi; Shimizu, Hiroshi; Y amaguchi, Etsuro; Nishimura, Masaharu }\end{array}$ \\
\hline Citation & $\begin{array}{l}\text { A merican Journal of Respiratory and Critical Care Medicine, 174(10), 1119-1124 } \\
\text { https://doi.org/10.1164/rccm.200601-0810 C }\end{array}$ \\
\hline Issue Date & 2006-11-15 \\
\hline Doc URL & http:/hdl.handle.net/2115/17081 \\
\hline Tyре & article \\
\hline File Information & A JR\& CCM17410.pdf \\
\hline
\end{tabular}

Instructions for use 


\title{
Polymorphisms in the Muscarinic Receptor 1 Gene Confer Susceptibility to Asthma in Japanese Subjects
}

\author{
Yukiko Maeda, Nobuyuki Hizawa, Eisei Jinushi, Ayumi Honda, Daisuke Takahashi, Yoshinobu Fukui, \\ Satoshi Konno, Tadamichi Shimizu, Hiroshi Shimizu, Etsuro Yamaguchi, and Masaharu Nishimura \\ First Department of Medicine and Department of Dermatology, Hokkaido University Graduate School of Medicine, Sapporo, Japan
}

\begin{abstract}
Rationale: The human cholinergic receptor muscarinic-1 (CHRM1) is widely distributed in the lungs. In patients with asthma, CHRM1 may be involved in airway constriction, airway epithelial cell proliferation, and airway inflammation. The CHRM1 gene is located on chromosome 11q13, which is one of the candidate loci for asthma and atopy.

Objectives: To determine the role of the CHRM1 gene polymorphisms in asthma.

Methods: We studied nine single-nucleotide polymorphisms $(-18379 \mathrm{G}>\mathrm{A},-9697 \mathrm{C}>\mathrm{T},-6965 \mathrm{~T}>\mathrm{C},-4953 \mathrm{~A}>\mathrm{G},+267 \mathrm{~A}>$ C, $+1353 \mathrm{C}>\mathrm{T},+3970 \mathrm{C}>\mathrm{G},+5418 \mathrm{C}>\mathrm{G}$, and $+5455 \mathrm{C}>\mathrm{T}$ ) in a case-control study using 326 patients with asthma and 333 healthy control subjects. We also examined functional consequences of the $-9697 \mathrm{C}>\mathrm{T}$ and $-4953 \mathrm{~A}>\mathrm{G}$ polymorphisms at the regulatory region using an mRNA reporter assay.

Measurements and Main Results: Two common single-nucleotide polymorphisms $(-9697 \mathrm{C}>\mathrm{T}$ and $-4953 \mathrm{~A}>\mathrm{G})$ were associated with asthma. The odds ratio for the TT homozygotes at the $-9697 \mathrm{C}$ $>\mathrm{T}$ polymorphism was 0.29 compared with the $\mathrm{CC}$ homozygotes (95\% confidence interval, $0.12-0.73 ; p=0.008)$, and the odds ratio for the GG homozygotes at the $-4953 \mathrm{~A}>\mathrm{G}$ polymorphism was 1.86 compared with the AA homozygotes ( $95 \%$ confidence interval, $1.04-3.34 ; p=0.038$ ). Haplotype analysis showed that the -9697T/ $-6965 \mathrm{~T} /-4953 \mathrm{~A}$ haplotype was associated with a lower risk of asthma $(p=0.00055)$ and the $-9697 \mathrm{C} /-6965 \mathrm{~T} /-4953 \mathrm{G}$ haplotype was associated with an increased risk of asthma $(p=0.020)$. The $-9697 \mathrm{~T} / 4953 \mathrm{~A}$ haplotype was also associated with lower luciferase activity in vitro compared with the $-9697 \mathrm{C} /-4953 \mathrm{C}$ haplotype. Conclusions: This study, together with an in vitro functional study, suggests that the CHRM1 gene is an important susceptibility locus for asthma on chromosome11q13.
\end{abstract}

Keywords: case-control studies; IgE; muscarinic cholinergic receptor-1; single-nucleotide polymorphism

The cholinergic nerves are the dominant neural bronchoconstrictor pathway in humans (1). They release acetylcholine onto muscarinic receptors causing cholinergic bronchoconstriction (2), mucous hypersecretion, and edema in the airways. Increases in cholinergic nerve activity and cholinergic hypersensitivity are associated with asthma, and patients with asthma are hypersensitive to the bronchoconstricting actions of muscarinic agonists (3). The human cholinergic receptor muscarinic 1 (CHRM1; Online Mendelian Inheritance of Man database no. 118510) is widely localized in the human lung, including the alveolar walls,

(Received in original form January 19, 2006; accepted in final form August 24, 2006) Supported by the Japan Society for the Promotion of Science (grant 17590771). Correspondence and requests for reprints should be addressed to Nobuyuki Hizawa, M.D., First Department of Medicine, Hokkaido University Graduate School of Medicine, N-15 W-7, Kita-Ku, Sapporo 060-8638, Japan. E-mail: nhizawa@med.hokudai.ac.jp

This article has an online supplement, which is accessible from this issue's table of contents at www.atsjournals.org

Am J Respir Crit Care Med Vol 174. pp 1119-1124, 2006

Originally Published in Press as DOI: 10.1164/rccm.200601-0810C on August 24, 2006 Internet address: www.atsjournals.org

\section{AT A GLANCE COMMENTARY}

Scientific Knowledge on the Subject

Genetic studies repeatedly have linked asthma and asthmarelated phenotypes to chromosome 11q13, on which several biological candidate genes are located.

What This Study Adds to the Field

Gene coding the human cholinergic receptor muscarinic-1 (CHRM1) is an important susceptibility locus for asthma at chromosome 11q13.

bronchial epithelial cells, parasympathetic ganglia, neuromuscular junction, and submucosal glands (4). Studies using pirenzepine, a muscarinic antagonist selective for M1 receptors, have shown that M1 muscarinic receptors are involved in vagally induced bronchoconstriction (5-7). M1 receptor-deficient mice showed increased bronchoconstriction in response to $10^{-8} \mathrm{M}$ muscarine in peripheral airways (8), suggesting the existence of an M1 receptor-dependent pathway counteracting cholinergic bronchoconstriction. M1 receptors also play a role in mast cell function (9), epithelial cell proliferation in the trachea (10), release of neutrophil and monocyte chemotactic activity from epithelial cells (11), acetylcholine-induced relaxation of the human pulmonary veins (12), and regulation of water and electrolyte secretion on submucosal glands (13). Taken together, CHRM1 is critically involved in the pathophysiology of asthma.

The gene encoding CHRM1 exists on chromosome 11q13, which has been linked to asthma and asthma-related phenotypes in several genomewide searches (14-17). Given the important role of muscarinic cholinergic mechanisms in asthma, the CHRM1 gene is biologically an excellent candidate for asthma susceptibility in the region of chromosome 11q13. Thus, in the current study, we examined whether genetic variations in the CHRM1 gene are associated with asthma. To gain insight into the possible molecular basis of the disease association, we also examined functional consequences of single-nucleotide polymorphisms (SNPs) at the regulatory region of the CHRM1 gene.

\section{METHODS}

See online supplement for additional details.

\section{Study Subjects}

A total of 659 unrelated Japanese adults were enrolled in the study (Table 1). Asthma was defined on the basis of recurrent episodes of at least two of three symptoms (cough, wheeze, and dyspnea) that are associated with demonstrable reversible airflow limitation (15\% variability in $\mathrm{FEV}_{1}$ or in peak expiratory flow rate either spontaneously or with an inhaled, short-acting $\beta_{2}$-agonist), or increased airway responsiveness to methacholine, or both, as described elsewhere (18). 
TABLE 1. BASIC CHARACTERISTICS OF 659 JAPANESE SUBJECTS

\begin{tabular}{|c|c|c|c|}
\hline & $\begin{array}{l}\text { Healthy Control Subjects } \\
\qquad(n=333)\end{array}$ & $\begin{array}{l}\text { Subjects with Asthma } \\
\qquad(n=326)\end{array}$ & p Value* \\
\hline Age, yr, median (range) & $41(18-72)$ & $45(16-79)$ & $<0.0001$ \\
\hline Sex, n (male/female) & $208 / 125$ & $148 / 178$ & $<0.0001$ \\
\hline Smoking, n (never/ex-/current) & $226 / 12 / 95$ & $190 / 69 / 67$ & $<0.0001$ \\
\hline Atopy, n (\%) & $170(51)$ & $237(73)$ & $<0.0001$ \\
\hline Total serum lgE, log IU/ml, mean (SD) & $1.84(0.627)$ & $2.40(0.622)$ & $<0.0001$ \\
\hline $\mathrm{FEV}_{1}, \%$ predicted, mean (SD) & - & $69.2(13.5)$ & \\
\hline$\%$ Reversibility in $\mathrm{FEV}_{1}$, median (range) & - & $16.9(0-211)$ & \\
\hline
\end{tabular}

* One-way analysis of variance or $\chi^{2}$ test was used where appropriate.

\section{Identification of Polymorphisms}

Genomic DNA from Japanese subjects was genotyped for $+267 \mathrm{~A}>$ $\mathrm{C}(\mathrm{rs} 2067477)$ and $+1353 \mathrm{C}>\mathrm{T}$ (rs2067480), because an association of these polymorphisms at the muscarinic $\mathrm{M} 1$ receptor gene with cognitive function in schizophrenic patients has been reported (19). We selected an additional seven SNPs for genotyping based on the frequency and location of SNPs and the linkage disequilibrium (LD) structure in and around the CHRM1 gene. We initially obtained genotyping data of 26 HapMap SNPs (spanning $31.6 \mathrm{~kb}$ around the gene) from 45 unrelated Japanese subjects at the International HapMap Project (available online at http://hapmap.org/). To select tagSNPs in this region, we used the multimarker predictor method implemented in the Tagger program (20). Tag set was generated (using a threshold $r^{2}$ of 0.8 ) using 14 common SNPs with a minor allele frequency of more than 0.05 in the Japanese population.

As the $+267 \mathrm{~A}>\mathrm{C}$ and $+1353 \mathrm{C}>\mathrm{T}$ polymorphisms were in a complete LD, we genotyped a total of eight SNPs $(-18379 \mathrm{G}>\mathrm{A}$ [rs1938677], -9697C > T [rs2075748], -6965T > C [rs542269], -4953A $>\mathrm{G}$ [rs1942499], +1353C $>\mathrm{T}$ [rs2067480], 3970C $>\mathrm{G}$ [rs4963323], 5418C > G [rs11601597], and 5455G > T [rs11605665]) for all individuals $(\mathrm{n}=659)$. These SNPs were typed using the assay that combines kinetic (real-time quantitative) polymerase chain reaction (PCR) with allele-specific amplification, as described elsewhere (18). The PCR products were detected using the ABI 7700 Sequence Detection System with the dsDNA-specific fluorescent dye SYBR Green I (Applied Biosystems, Foster City, CA). The $-4953 \mathrm{~A}>\mathrm{G}$ polymorphism was typed using TaqMan assay (Applied Biosystems).

\section{Statistical Analysis}

The association of the CHRM1 gene polymorphism was measured by odds ratio (OR) with $95 \%$ confidence intervals (CI) as estimates of relative risk for the development of asthma. We used the HardyWeinberg equilibrium (HWE) program (21) to compare observed numbers of genotypes with the numbers of genotypes expected under HWE. For haplotype analyses, we used the Haplo.score program, which adjusts for covariates and calculates simulation $\mathrm{p}$ values for each haplotype (22).

\section{Luciferase Reporter Gene Assay}

We constructed two promoter reporter plasmids by placing two haplotypes $(-9697 \mathrm{C} /-4953 \mathrm{G}$ and $-9697 \mathrm{~T} /-4953 \mathrm{~A})$ into the pGL3-Basic vector. Human neuroblastoma IMR32 cells $\left(1 \times 10^{6}\right)$ were transiently transfected with $9.5 \mu \mathrm{g}$ of one of the two constructs and $0.5 \mu \mathrm{g}$ of the pRL-TK vector, an internal control for transfection efficiency. After $24 \mathrm{~h}$, we measured luciferase activity using the Dual-Luciferase Reporter Assay System (Promega, Tokyo, Japan). Results were expressed as means \pm SEM and were compared by paired $t$ test.

\section{Electrophoretic Mobility Shift Assay}

Transcription factor (nuclear factor $[\mathrm{NF}]-\kappa \mathrm{B}$ or upstream stimulating factor [USF]-1)-DNA binding activity was analyzed using the electrophoretic mobility shift assay (EMSA) kit (Panomics, Redwood, CA), according to the manufacturer's instructions.

\section{RESULTS}

Characteristics of the 333 healthy control subjects and 326 subjects with asthma are shown in Table 1 . The median age of subjects with asthma was significantly higher than in healthy control subjects $(\mathrm{p}<0.0001)$. There were significantly more females in the asthma group than in the control group $(\mathrm{p}<$ 0.0001). Subjects with asthma were more likely to be atopic and had higher levels of total serum $\operatorname{IgE}$ than did healthy control subjects $\left(\chi^{2}\right.$ test or analysis of variance, $\left.p<0.0001\right)$. More than $50 \%$ of the control subjects were atopic, which is consistent with

TABLE 2. COMPARISONS OF ALLELE AND GENOTYPE FREQUENCIES OF EIGHT CHRM1 SINGLE-NUCLEOTIDE POLYMORPHISMS BETWEEN PATIENTS WITH ASTHMA AND CONTROL SUBJECTS

\begin{tabular}{|c|c|c|c|c|}
\hline SNP & Allele/Genotype & $\begin{array}{c}\mathrm{HC} \\
n(\%)\end{array}$ & $\begin{array}{c}\text { BA } \\
n(\%)\end{array}$ & p Value* \\
\hline \multirow[t]{5}{*}{-18379 (rs1938677) } & G & $361(54.5)$ & $335(48.1)$ & 0.33 \\
\hline & $A$ & $301(45.5)$ & 311 (51.9) & \\
\hline & GG & $107(32.3)$ & $92(28.5)$ & 0.56 \\
\hline & GA & $146(44.1)$ & $151(46.7)$ & \\
\hline & $\mathrm{AA}$ & $78(23.6)$ & $80(24.8)$ & \\
\hline \multirow[t]{5}{*}{-9697 (rs2075748) } & $\mathrm{C}$ & $508(76.3)$ & $533(81.7)$ & 0.015 \\
\hline & $\mathrm{T}$ & $158(23.7)$ & $119(18.3)$ & \\
\hline & $\mathrm{CC}$ & $195(58.6)$ & $216(66.3)$ & 0.039 \\
\hline & $\mathrm{CT}$ & $118(35.4)$ & $101(31.0)$ & \\
\hline & $\mathrm{TT}$ & $20(6.0)$ & $9(2.7)$ & \\
\hline \multirow[t]{5}{*}{-6965 (rs542269) } & $\mathrm{T}$ & $491(73.9)$ & $472(73.1)$ & 0.72 \\
\hline & $\mathrm{C}$ & $173(26.1)$ & $174(26.9)$ & \\
\hline & TT & $184(55.4)$ & $175(54.2)$ & 0.94 \\
\hline & $\mathrm{TC}$ & $123(37.1)$ & $122(37.8)$ & \\
\hline & $\mathrm{CC}$ & $25(7.5)$ & $26(8.0)$ & \\
\hline \multirow[t]{5}{*}{-4953 (rs1942499) } & A & $477(71.6)$ & $434(66.6)$ & 0.047 \\
\hline & G & $189(28.4)$ & $218(33.4)$ & \\
\hline & $A A$ & $174(52.3)$ & $147(45.1)$ & 0.15 \\
\hline & AG & $129(38.7)$ & $140(42.9)$ & \\
\hline & GG & $30(9.0)$ & $39(12.0)$ & \\
\hline \multirow[t]{5}{*}{ +1353 (rs2067480) } & $\mathrm{C}$ & $615(92.3)$ & $608(93.3)$ & 0.52 \\
\hline & $\mathrm{T}$ & $51(7.7)$ & $44(6.7)$ & \\
\hline & $\mathrm{CC}$ & $284(85.3)$ & $287(88.0)$ & 0.19 \\
\hline & $\mathrm{CT}$ & $47(14.1)$ & $34(10.5)$ & \\
\hline & $\mathrm{TT}$ & $2(0.6)$ & $5(1.5)$ & \\
\hline \multirow[t]{5}{*}{ +3970 (rs4963323) } & $\mathrm{C}$ & $533(80.3)$ & $524(80.9)$ & 0.78 \\
\hline & G & $131(19.7)$ & $124(19.1)$ & \\
\hline & $\mathrm{CC}$ & $216(65.1)$ & $211(65.1)$ & 0.75 \\
\hline & CG & $101(30.4)$ & $102(31.5)$ & \\
\hline & GG & $15(4.5)$ & $11(3.4)$ & \\
\hline \multirow[t]{5}{*}{ +5418 (rs11601597) } & $\mathrm{C}$ & $414(62.3)$ & $385(59.6)$ & 0.31 \\
\hline & G & $250(37.7)$ & $261(40.4)$ & \\
\hline & $\mathrm{CC}$ & $132(39.7)$ & $113(35.0)$ & 0.44 \\
\hline & CG & $150(45.2)$ & $159(49.2)$ & \\
\hline & GG & $50(15.1)$ & $51(15.8)$ & \\
\hline \multirow[t]{5}{*}{ +5455 (rs11605665) } & G & $538(81.5)$ & $496(77.5)$ & 0.074 \\
\hline & $\mathrm{T}$ & $122(18.5)$ & $144(22.5)$ & \\
\hline & GG & $218(66.1)$ & $192(60.0)$ & 0.19 \\
\hline & GT & $102(30.9)$ & $112(35.0)$ & \\
\hline & TT & $10(3.0)$ & $16(5.0)$ & \\
\hline
\end{tabular}

Definition of abbreviations: $\mathrm{BA}=$ bronchial asthma; $\mathrm{HC}=$ healthy controls ${ }^{*} \chi^{2}$ Test. 
recent findings that the prevalence of atopy (as indicated by specific IgE against common inhaled allergens) among Japanese subjects is increasing $(23,24)$. Prebronchodilator baseline $\mathrm{FEV}_{1}$ at an initial visit to our hospital was examined for 293 subjects with asthma $(89.9 \%)$, and improvement of $\mathrm{FEV}_{1}$ after bronchodilator therapy (400 $\mu \mathrm{g}$ salbutamol) or after a course of standard asthma medications (inhaled corticosteroids, longacting $\beta_{2}$-agonists, theophylline, or leukotriene modulators) was recorded for $214(65.6 \%)$ subjects with asthma (Table 1).

All eight of the SNPs investigated were within the HWE in the control group $(\mathrm{p}>0.05)$. The overall success rate for genotyping was $99.6 \%$. Of the eight SNPs, two common SNPs $(-9697 \mathrm{C}>\mathrm{T}$ [rs2075748] and -4953A $>\mathrm{G}$ [rs1942499]) in the regulatory region of the CHRM1 gene had a significant association with asthma (Table 2). Both of these SNPs were significantly associated with asthma when the analysis was adjusted for age, sex, smoking status, and atopic status (Table 3). The OR for the TT homozygotes of the $-9697 \mathrm{C}>\mathrm{T}$ polymorphism was 0.29 compared with the CC homozygotes $(95 \% \mathrm{CI}$, $0.12-0.73 ; p=0.008)$, and the OR for the GG homozygotes of the $-4953 \mathrm{~A}>\mathrm{G}$ polymorphism was 1.86 compared with the AA homozygotes (95\% CI, 1.04-3.34; $\mathrm{p}=0.038$ ).

We analyzed data from the eight SNPs with the Haploview program (25) and identified two haplotype blocks (Figure 1) in our case-control population. Haplotype block I comprised three SNPs in the regulatory region $(-9697 \mathrm{C}>\mathrm{T}$ [rs2075748], $-6965 \mathrm{~T}$ $>\mathrm{C}$ [rs542269], -4953A > G [rs1942499]), and haplotype block II comprised three SNPs $(+1353 \mathrm{C}>\mathrm{T}[\mathrm{rs} 2067480],+3970 \mathrm{C}>$
$\mathrm{G}$ [rs4963323], +5418C > G [rs11601597]) in the coding exon and the 3 '-UTR. Haplotype analyses were performed in both blocks I and II. The frequency of CHRM1 haplotypes is shown in Table 4. In block I, the -9697T/-6965T/-4953A haplotype was associated with a significantly lower risk of asthma $(\mathrm{p}=$ $0.00055)$ and the $-9697 \mathrm{C}-6965 \mathrm{~T} /-4953 \mathrm{G}$ haplotype was associated with a significantly increased risk of asthma $(p=0.020)$. Inspection of specific haplotypes revealed that this association is most likely due to $-9697 \mathrm{C}>\mathrm{T}$ and $-4953 \mathrm{~A}>\mathrm{G}$, because the same allele for $-6965 \mathrm{~T}>\mathrm{C}$ is part of both risk and protective haplotypes. In contrast, none of the haplotypes in block II was associated with asthma.

In the case-only study, associations between asthma-related phenotypes, such as total serum IgE levels and atopy, and the polymorphisms of $C H R M 1$ were also investigated. We could not find any significant association between the genotypes of the eight SNPs and total serum IgE levels or atopy (see Tables E1 and E2 in the online supplement).

The transcriptional activity of the CHRM1 SNPs at the regulatory region was compared between the $-9697 \mathrm{C} /-4953 \mathrm{G}$ haplotype and the $-9697 \mathrm{~T} /-4953 \mathrm{~A}$ haplotype transiently transfected into human neuroblastoma IMR32 cells. Luciferase activity in cell extracts was assessed $24 \mathrm{~h}$ after transfection, and was expressed as fold increase in the activity of the CHRM1 reporter constructs compared with the pRL-TK vector. Figure 2 shows that the reporter plasmid carrying the $-9697 \mathrm{~T} /-4953 \mathrm{~A}$ promoter displayed $37 \%$ lower transcriptional activity compared with the plasmid carrying the $-9697 \mathrm{C} /-4953 \mathrm{G}$ promoter $(\mathrm{p}=0.019)$.

TABLE 3. GENETIC IMPACT ON ASTHMA OF EIGHT SINGLE-NUCLEOTIDE POLYMORPHISMS IN AND AROUND THE CHRM1 GENE

\begin{tabular}{|c|c|c|c|}
\hline \multirow[b]{2}{*}{ SNP } & \multirow[b]{2}{*}{ Genotype } & \multicolumn{2}{|c|}{ OR $(95 \% \mathrm{Cl})$} \\
\hline & & Adjustments (-) & Adjustments $(+)^{*}$ \\
\hline \multirow[t]{3}{*}{$-18379 G>A(r s 1938677)$} & GG & 1 (Reference) & 1 (Reference) \\
\hline & GA & $1.20(0.84-1.72)$ & $1.14(0.77-1.71)$ \\
\hline & AA & $1.19(0.79-1.81)$ & $1.33(0.84-2.12)$ \\
\hline \multirow[t]{3}{*}{$-9697 \mathrm{C}>\mathrm{T}(\mathrm{rs} 2075748)$} & $\mathrm{CC}$ & 1 (Reference) & 1 (Reference) \\
\hline & $\mathrm{CT}$ & $0.77(0.56-1.07)$ & $0.73(0.51-1.06)$ \\
\hline & $\mathrm{TT}$ & $0.41(0.18-0.91)^{\dagger}$ & $0.29(0.12-0.73)^{\ddagger}$ \\
\hline \multirow{3}{*}{$-6965 \mathrm{~T}>\mathrm{C}(\mathrm{rs} 542269)$} & TT & 1 (Reference) & 1 (Reference) \\
\hline & $\mathrm{TC}$ & $1.04(0.75-1.44)$ & $1.00(0.70-1.44)$ \\
\hline & $\mathrm{CC}$ & $1.09(0.61-1.97)$ & $1.04(0.54-2.02)$ \\
\hline \multirow[t]{3}{*}{$-4953 \mathrm{~A}>\mathrm{G}(\mathrm{rs} 1942499)$} & $\mathrm{AA}$ & 1 (Reference) & 1 (Reference) \\
\hline & AG & $1.28(0.93-1.78)$ & $1.38(0.96-1.98)$ \\
\hline & GG & $1.54(0.91-2.60)$ & $1.86(1.04-3.34)^{\dagger}$ \\
\hline \multirow[t]{3}{*}{$+1353 \mathrm{C}>\mathrm{T}(\mathrm{rs} 2067480)$} & $\mathrm{CC}$ & 1 (Reference) & 1 (Reference) \\
\hline & $\mathrm{CT}$ & $0.72(0.45-1.15)$ & $0.61(0.37-1.02)$ \\
\hline & $\mathrm{TT}$ & $2.47(0.48-12.9)$ & $1.96(0.31-12.5)$ \\
\hline \multirow[t]{3}{*}{$+3970 \mathrm{C}>\mathrm{G}(\mathrm{rs} 4963323)$} & $\mathrm{CC}$ & 1 (Reference) & 1 (Reference) \\
\hline & CG & $1.03(0.74-1.44)$ & $1.12(0.78-1.62)$ \\
\hline & GG & $0.75(0.34-1.67)$ & $0.78(0.33-1.86)$ \\
\hline \multirow[t]{3}{*}{$+5418 \mathrm{C}>\mathrm{G}(\mathrm{rs} 11601597)$} & $\mathrm{CC}$ & 1 (Reference) & 1 (Reference) \\
\hline & CG & $1.24(0.88-1.73)$ & $1.29(0.89-1.88)$ \\
\hline & GG & $1.19(0.75-1.89)$ & $1.16(0.70-1.93)$ \\
\hline \multirow[t]{3}{*}{$+5455 \mathrm{G}>\mathrm{T}(\mathrm{rs} 11605665)$} & GG & 1 (Reference) & 1 (Reference) \\
\hline & GT & $1.25(0.90-1.74)$ & $1.28(0.89-1.85)$ \\
\hline & $\mathrm{TT}$ & $1.82(0.81-4.1)$ & $1.73(0.73-4.09)$ \\
\hline
\end{tabular}

Definition of abbreviations: $\mathrm{Cl}=$ confidence interval; $\mathrm{OR}=$ odds ratio.

* Adjustment for matching factors and potential confounding factors, including sex, age, smoking status, and atopic status, was performed by unconditional logistic regression analysis.

$+\mathrm{p}<0.05$.

${ }_{*} p<0.01$. 


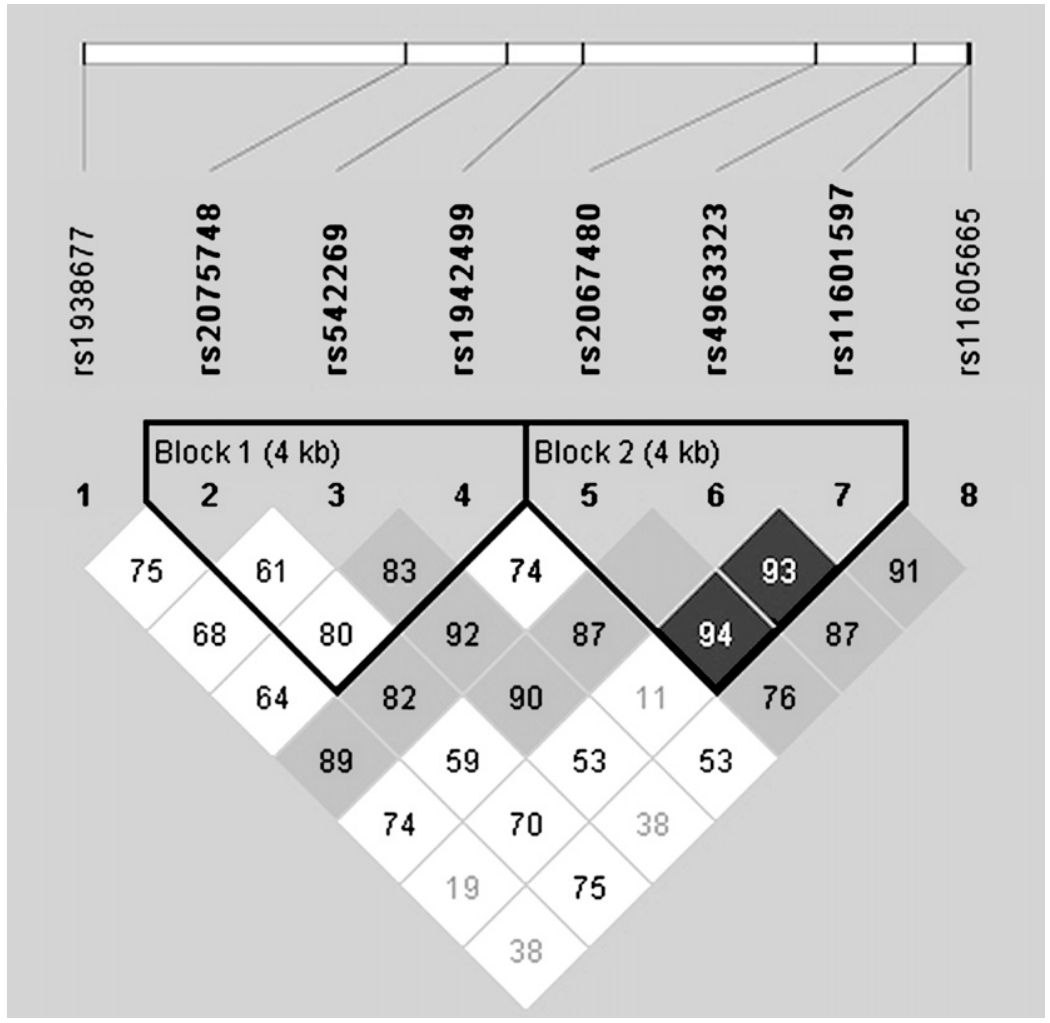

Figure 1. Locations and linkage disequilibrium (LD) map structure of single-nucleotide polymorphisms (SNPs) in and around the CHRM1 Haploview plot shows pairwise LD ( $D^{\prime}$ values) for 8 SNPs based on genotypes of 659 individuals of the case-control study. The eight SNPs include $-18379 \mathrm{C}>\mathrm{A}$ [rs1938677], $-9697 \mathrm{C}>\mathrm{T}$ [rs2075748], $-6965 \mathrm{~T}>\mathrm{C}[\mathrm{rs} 542269],-4953 \mathrm{~A}>\mathrm{G}$ [rs1942499], +1353C > T [rs2067480], +3970C > G [rs4963323], $+5418 \mathrm{C}>\mathrm{G}[\mathrm{rs} 11601597]$, and $+5455 \mathrm{G}>$ T [rs11605665]. LD blocks are framed in black and were classified according to the "solid spine" option (25). Each square plots the level of LD ( $\mathrm{D}^{\prime}$ values) between a pair of SNPs.

This difference in transcriptional activity was consistent in eight independent experiments.

EMSA failed to show a robust difference in binding affinity of NF-kB to the $-9697 \mathrm{~T}$ or the $-9697 \mathrm{C}$ allele, or in binding affinity of USF-1 to the $-4953 \mathrm{~A}$ or the $-4953 \mathrm{G}$ allele (data not shown).

\section{DISCUSSION}

Given a high a priori biological plausibility for asthma, we tested the hypothesis that the allelic variants at the regulatory region of the CHRM1 confer susceptibility to asthma by conducting a case-control study in a relatively large population of unrelated Japanese subjects. In accordance with our primary hypothesis, we found that the presence of the $-9697 \mathrm{CC}$ genotype, -4953GG genotype, or the $-9697 \mathrm{C} /-4953 \mathrm{G}$ haplotype at the regulatory region was significantly associated with a diagnosis of asthma. Our genetic association study had several strengths: first, muscarinic receptors, including $\mathrm{M} 1$, have been biologically implicated in the pathogenesis of asthma; second, the gene encoding the CHRM1 is located on chromosome 11q13, a genomic region

TABLE 4. ESTIMATED HAPLOTYPE FREQUENCIES OF THE CHRM1 GENE POLYMORPHISMS

\begin{tabular}{|c|c|c|c|c|c|c|c|}
\hline & & & & \multicolumn{2}{|c|}{ Haplotype Frequency } & \multirow[b]{2}{*}{ Haplotype-specific Score } & \multirow[b]{2}{*}{$\mathrm{p}$ Value $^{*}$ (Empirical) } \\
\hline & & & & $\begin{array}{c}\text { Control } \\
(n=333)\end{array}$ & $\begin{array}{c}\text { Asthma } \\
(n=326)\end{array}$ & & \\
\hline \multicolumn{8}{|l|}{ Block I } \\
\hline Haplotype & \multicolumn{7}{|c|}{$-9697 /-6965 /-4953$} \\
\hline 1 & $\mathrm{~T}$ & $\mathrm{~T}$ & A & 0.207 & 0.158 & -3.03 & 0.00055 \\
\hline 2 & C & C & A & 0.239 & 0.234 & -0.23 & 0.827 \\
\hline 3 & C & $\mathrm{T}$ & A & 0.250 & 0.254 & 0.057 & 0.959 \\
\hline 4 & c & $\mathrm{T}$ & G & 0.268 & 0.303 & 2.15 & 0.020 \\
\hline \multicolumn{8}{|l|}{ Block II } \\
\hline Haplotype & \multicolumn{7}{|c|}{$+1353 /+3970 /+5418$} \\
\hline 1 & $\mathrm{~T}$ & C & C & 0.371 & 0.391 & 0.120 & 0.131 \\
\hline 2 & C & C & C & 0.353 & 0.349 & 0.808 & 0.814 \\
\hline 3 & C & G & C & 0.192 & 0.179 & 0.926 & 0.918 \\
\hline 4 & C & C & G & 0.371 & 0.391 & 0.454 & 0.481 \\
\hline
\end{tabular}

Haplotype frequencies were estimated using the Haplo.Stats program. In Block I (regulatory region of the gene), haplotype analyses showed that the $-9697 \mathrm{~T} /-6965 \mathrm{~T} /-4953 \mathrm{~A}$ haplotype was associated with a significantly lower risk of asthma $(p=$ $0.00055)$ and the $-9697 \mathrm{C} /-6965 \mathrm{~T} /-4953 \mathrm{G}$ haplotype was associated with a significantly increased risk of asthma $(p=0.020)$. In contrast, in Block II, none of haplotypes showed a significant association with asthma. Note that haplotype-specific scores give effect estimates; negative haplotype-specific scores are associated with a protective effect, and positive haplotype-specific scores are associated with an increased risk. Haplotypes with frequencies less than 0.05 were excluded from the analyses. 


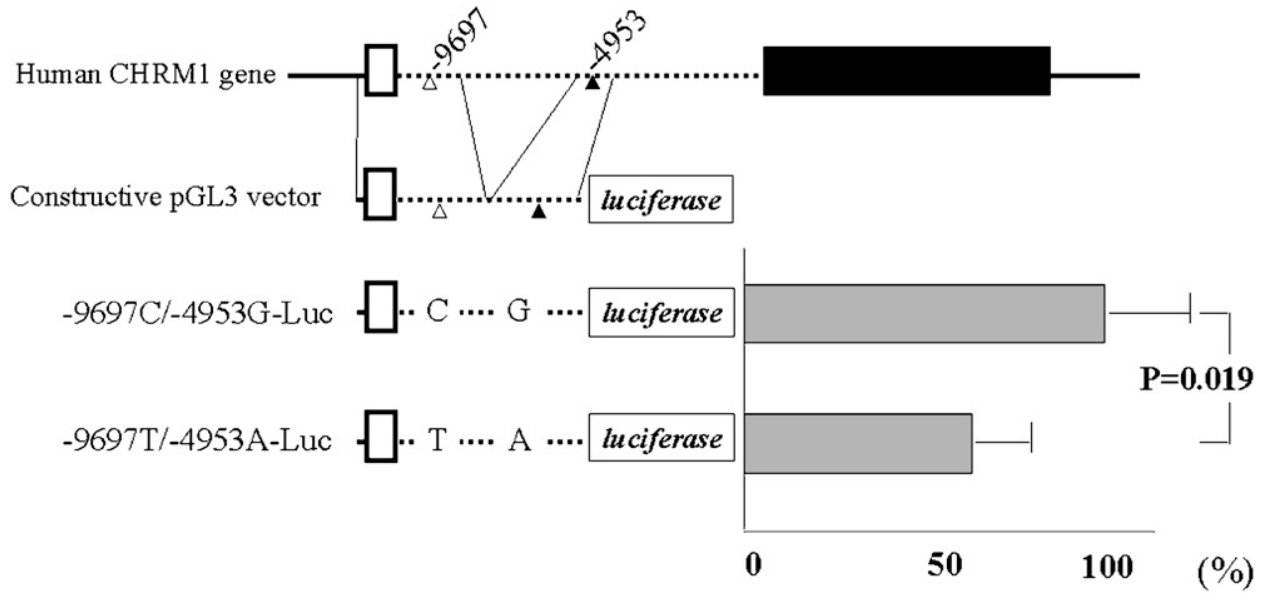

Relative Promoter Activity (\% of $-9697 \mathrm{C} /-4953 \mathrm{G}-\mathrm{LUC}$ levels)
Figure 2. Transcription activity analysis of the promoter region of CHRM1 IMR32 cells were transiently transfected with $9.5 \mu \mathrm{g}$ of CHRM1 luciferase reporter constructs (schematically depicted to the left) plus $0.5 \mu \mathrm{g}$ of $\mathrm{pRL}-\mathrm{TK}$ vector. Luciferase activities were normalized against the internal control Renilla values. The data represent means \pm SD for the entire dataset (four independent experiments, each in duplicate), and are expressed as a percentage of the $-9697 \mathrm{C} /-4953 \mathrm{G}$ LUC activity. The difference between these constructs was significant at $\mathrm{p}=0.019$ (paired $t$ test; $\mathrm{n}=8$ ).

\section{.......Intron $\square$ Non coding exon $\square$ Coding exon}

linked to the diagnosis of asthma and atopy in several genomewide scans (14-17); third, in vitro functional analyses have shown that the haplotype at the regulatory region has an effect on a basal promoter function in IMR32 cells, with the $-9697 \mathrm{~T} /$ -4953A haplotype associated with $37 \%$ decreased promoter activity compared with the $-9697 \mathrm{C} /-4953 \mathrm{G}$ haplotype. Accordingly, our data suggest that the $-9697 /-4953$ haplotype may influence the affinity of a particular nuclear protein to the regulatory region of the $C H R M 1$ gene, resulting in altered transcriptional activity and ultimately leading to a higher or lower risk of asthma.

Although the exact mechanisms underlying the involvement of the CHRM1 gene in the pathogenesis of asthma remain to be identified, several reports indicate that the cholinergic pathway has an important role in the pathogenesis of asthma, in particular in the regulation of bronchoconstriction, airway inflammation, and airway remodeling. An M1 receptordependent pathway counteracts cholinergic bronchoconstriction, possibly via the release of a relaxing agent (8); both respiratory epithelia and sympathetic nerve terminals within bronchial smooth muscle are equipped with M1 receptors $(7,26)$ and releasable bronchodilating agents, such as nitric oxide and prostaglandin $\mathrm{E}_{2}$ (27). Studies with the M1 receptor-preferring antagonist, pirenzepine, have also suggested the existence of pulmonary M1 receptors modulating airway diameter (28). Furthermore, Jones and colleagues (29) demonstrated that stable expression in RBL-2H3 mast cells of the M1 muscarinic acetylcholine receptor leads to carbachol-stimulated mast cell degranulation. An animal model of asthma showed that anticholinergic agents protect against allergen-induced airway remodeling (30). Together with these in vivo and in vitro findings, our findings support the contention that CHRM1 plays an important role in the pathogenesis of asthma. Our findings may be of considerable relevance to asthma treatment, providing an important basis for identification of individuals for whom the cholinergic pathway could be targeted.

Sequence analysis indicated that the $\mathrm{T}$ allele at the $-9697 \mathrm{C}>$ $\mathrm{T}$ polymorphism creates a potential NF- $\mathrm{KB}$ binding site and that the $\mathrm{A}$ allele at the $-4953 \mathrm{~A}>\mathrm{G}$ polymorphism creates a potential USF-1 transcription factor binding site by reference to the MatInspector or TFSEARCH database (31). We, however, failed to see any difference in binding intensities of these nuclear factors to the $-9697 \mathrm{C}>\mathrm{T}$ or $-4953 \mathrm{~A}>\mathrm{G}$ polymorphism.
Therefore, we cannot exclude the possibility that these SNPs might not be causative in nature, but are in LD with a true susceptibility allele in the regulatory region of the $C H R M 1$ gene. Population stratification may influence the observed associations (32). However, our population is racially homogeneous, as all subjects recruited in the study were from the Japanese population, which is considered monoracial; thus, our subjects had a relatively low risk of population stratification effects. Furthermore, we recruited all participants in the current study from a single institute to minimize the chance of mixing populations with inherently diverse allele frequencies of a susceptibility gene. In addition, all SNPs were in HWE in a set of unrelated healthy subjects. Therefore, we believe that the usual problems associated with population stratification may be of limited importance in the present study. Nevertheless, we acknowledge that population stratification may have influenced the present findings, and that the findings of the current study are preliminary and do not, by themselves, conclusively confirm an etiologic relationship. A more comprehensive approach that examines the functional consequences of the CHRM1 promoter polymorphisms and identifies the possible promoter-dependent mechanism for an association between CHRM1 and asthma is required.

In conclusion, given the important role of muscarinic cholinergic mechanisms in pulmonary disease, this case-control study, together with an in vitro functional analysis, suggests that the CHRM1 gene is an important susceptibility locus for asthma at chromosome 11q13. The $-9697 /-4953$ haplotype at the regulatory region of the gene may contribute to the development of asthma by altering the human lung muscarinic receptor system in ways that could account for the increased in vivo lung cholinergic hyperresponsiveness found in patients with asthma.

Conflict of Interest Statement: None of the authors has a financial relationship with a commercial entity that has an interest in the subject of this manuscript.

Acknowledgment: The authors thank all of the subjects of this study for their participation. They also thank Yoshiko Obata and Tomoko Akiyama for their excellent technical assistance, and Takeshi Sawazaki at the Pharmaceutical Research Laboratory, Hitachi Chemical Co., Ltd., for kindly measuring Ag-specific IgE antibody levels (MAST).

\section{References}

1. Barnes PJ. Neural control of human airways in health and disease. Am Rev Respir Dis 1986;134:1289-1314. 
2. Watson N, Magnussen H, Robe KF. Pharmacological characterization of the muscarinic receptor subtype mediating contraction of human peripheral airway. J Pharmacol Exp Ther 1995;274:1293-1297.

3. Jacoby DB, Fryer AD. Anticholinergic therapy for airway diseases. Life Sci 2001;68:2565-2572.

4. Zaagsma J, Meurs H, Roffel AF. Muscarinic receptors in airways diseases. Basel, Switzerland: Birkhäuser Verlag; 2001.

5. Bloom JW, Yamaura HI, Baumgartener C, Halonen M. A muscarinic receptor with high affinity for pirenzepine mediates vagally induced bronchoconstriction. Eur J Pharmacol 1987;133:21-27.

6. Lammers JW, Minette P, McCusker M, Barnes PJ. The role of pirenzepinesensitive (M1) muscarinic receptors in vagally mediated bronchoconstriction in humans. Am Rev Respir Dis 1989;139:446-449.

7. Maclagan J, Fryer AD, Faulkner D. Identification of M1 muscarinic receptors in pulmonary sympathetic nerves in the guinea-pig by use of pirenzepine. Br J Pharmacol 1989;97:499-505.

8. Struckmann N, Schwering S, Wiegand S, Gschnell A, Yamada M, Kummer W, Wess J, Haberberger RV. Role of muscarinic receptor subtypes in the constriction of peripheral airways: studies on receptordeficient mice. Mol Pharmacol 2003;64:1444-1451.

9. Reinheimer T, Mohlig T, Zimmermann S, Hohle KD, Wessler I. Muscarinic control of histamine release from airways: inhibitory M1-receptors in human bronchi but absence in rat trachea. Am J Respir Crit Care Med 2000;162:534-538.

10. Metzen J, Bittinger F, Kirkpatrick CJ, Kilbinger H, Wessler I. Proliferative effect of acetylcholine on rat trachea epithelial cells is mediated by nicotinic receptors and muscarinic receptors of the M1-subtype. Life Sci 2003;72:2075-2080.

11. Koyama S, Rennard SI, Robbins RA. Acetylcholine stimulates bronchial epithelial cells to release neutrophil and monocyte chemotactic activity. Am J Physiol 1992;262:L466-L471.

12. Walch L, Gascard JP, Dulmet E, Brink C, Norel X. Evidence for a M1 muscarinic receptor on the endothelium of human pulmonary veins. Br J Pharmacol 2000;130:73-78.

13. Yang CM, Farley JM, Dwyer TM. Muscarinic stimulation of submucosal glands in swine trachea. J Appl Physiol 1988;64:200-209.

14. Daniels SE, Bhattacharrya S, James A, Leaves NI, Young A, Hill MR, Faux JA, Ryan GF, le Souef PN, Lathrop GM, et al. A genome-wide search for quantitative trait loci underlying asthma. Nature 1996;383: 247-250.

15. Los H, Koppelman GH, Postma DS. The importance of genetic influences in asthma. Eur Respir J 1999;14:1210-1227.

16. Malerba G, Pignatti PF. A review of asthma genetics: gene expression studies and recent candidates. J Appl Genet 2005;46:93-104.

17. Hizawa N, Yamaguchi E, Furuya K, Ohnuma N, Kodama N, Kojima J, Ohe M, Kawakami Y. Association between high serum total IgE levels and D11S97 on chromosome 11q13 in Japanese subjects. J Med Genet 1995;32:363-369.
18. Hizawa N, Yamaguchi E, Takahashi D, Nishihira J, Nishimura M. Functional polymorphisms in the promoter region of macrophage migration inhibitory factor and atopy. Am J Respir Crit Care Med 2004;169:10141018.

19. Liao DL, Hong CJ, Chen HM, Chen YE, Lee SM, Chang CY, Chen H, Tsai SJ. Association of muscarinic M1 receptor genetic polymorphisms with psychiatric symptoms and cognitive function in schizophrenic patients. Neuropsychobiology 2003;48:72-76.

20. de Bakker PI, Yelensky R, Pe'er I, Gabriel SB, Daly MJ, Altshuler D. Efficiency and power in genetic association studies. Nat Genet 2005; 37:1217-1223.

21. Terwillinger JD, Ott J. Handbook of human genetic linkage. Baltimore, MD: Johns Hopkins University Press; 1994.

22. Schaid DJ, Rowland CM, Tines DE, Jacobson RM, Poland GA. Score tests for association between traits and haplotypes when linkage phase is ambiguous. Am J Hum Genet 2002;70:425-434.

23. Nakagomi T, Itaya H, Tominaga T, Yamaki M, Hisamatsu S, Nakagomi O. Is atopy increasing? Lancet 1994;343:121-122.

24. Kusunoki T, Hosoi S, Asai K, Harazaki M, Furusho K. Relationships between atopy and lung function: results from a sample of one hundred medical students in Japan. Ann Allergy Asthma Immunol 1999;83:343347.

25. Barrett JC, Fry B, Maller J, Daly MJ. Haploview: analysis and visualization of LD and haplotype maps. Bioinformatics 2005;21:263-265.

26. Shapiro MS, Gomeza J, Hamilton SE, Hille B, Loose MD, Nathanson NM, Roche JP, Wess J. Identification of subtypes of muscarinic receptors that regulate $\mathrm{Ca}^{2+}$ and $\mathrm{K}^{+}$channel activity in sympathetic neurons. J Life Sci 2001;68:2481-2487.

27. Spicuzza L, Basile L, Belvisi MG, Bellofiore S, Matera MG, Cazzola M, Di Maria GU. The protective role of epithelium-derived nitric oxide in isolated bovine trachea. Pulm Pharmacol Ther 2002;15:357-362.

28. Bloom JW, Baumgartener-Folkerts C, Palmer JD, Yamamura HI, Halonen M. A muscarinic receptor subtype modulates vagally stimulated bronchial contraction. J Appl Physiol 1988;65:2144-2150.

29. Jones SV, Choi OH, Beaven MA. Carbachol induces secretion in a mast cell line (RBL-2H3) transfected with the ml muscarinic receptor gene. FEBS Lett 1991;289:47-50.

30. Gosens R, Bos IS, Zaagsma J, Meurs H. Protective effects of tiotropium bromide in the progression of airway smooth muscle remodeling. Am J Respir Crit Care Med 2005;171:1096-1102.

31. Quandt K, Frech K, Karas H, Wingender E, Werner T. MatInd and MatInspector: new fast and versatile tools for detection of consensus matches in nucleotide sequence data. Nucleic Acids Res 1995;23:48784884.

32. Freedman ML, Reich D, Penney KL, McDonald GJ, Mignault AA, Patterson N, Gabriel SB, Topol EJ, Smoller JW, Pato CN, et al. Assessing the impact of population stratification on genetic association studies. Nat Genet 2004:36:388-393. 